\title{
THE POSSIBILITY OF THE USE OF SECONDARY RAW MATERIALS FROM ENERGY AND IRON\&STEEL INDUSTRIES FOR GLASS-CERAMICS PRODUCTION
}

\section{MOŻLIWOŚĆ WYKORZYSTANIA SUROWCÓW WTÓRNYCH PRZEMYSKU ENERGETYCZNEGO I HUTNICZEGO DO WYTWARZANIA SZKKA-CERAMIKI}

DOI: $10.30540 / \mathrm{sae}-2018-011$

\begin{abstract}
A bstract
An effective way to glass strengthening is controlled crystallization, which results in obtaining the material with very favourable mechanical properties compared to parent glass. Crystallization process is conducted between glass transformation temperature and liquidus temperature. Information concerning the production of glass-ceramics material, as well as materials, which are the most commonly used in its production, were analyzed in this paper.
\end{abstract}

Keywords: wastes, glass-ceramics, blast-furnace slag, siliceous fly ash

\section{Streszczenie}

Skutecznym sposobem wzmocnienia szkła jest kontrolowana krystalizacja, co skutkuje otrzymaniem materiatu o bardzo dobrych właściwościach mechanicznych w porównaniu do szkła macierzystego. Proces krystalizacji prowadzony jest pomiędzy temperatura transformacji szkta a temperatura likwidusu. W artykule przenalizowano informacje dotyczace otrzymywania tworzywa szkło-ceramiki, jak również materiałów najczęściej wykorzystywanych podczas produkcji tego materiatu.

Słowa kluczowe: odpady, szkło-ceramika, żużel wielkopiecowy, popiół lotny krzemionkowy

\section{INTRODUCTION}

The wastes have always accompanied people. For many years, they have been thrown directly into the surrounding environment, which caused contamination with toxic substances. Materials defined as "wastes" are subject to strict legal regulations. In accordance with the Act of 27 April 2001 on wastes (Journal of Laws 2007, No. 39, item 251 - consolidated text) "wastes" shall mean all substances or objects in the categories set out in Annex 1 of the Act, which the holder discards (or is required to discard) [1]. Siliceous fly ash and granulated blast-

\section{WPROWADZENIE}

Odpady towarzyszą człowiekowi od zawsze. Przez lata były wyrzucane bezpośrednio do otaczającego środowiska, przez co dochodziło do skażenia substancjami toksycznymi. Materiały charakteryzowane jako „odpady” podlegają ścisłym uregulowaniom prawnym. Zgodnie z ustawą z dnia 27 kwietnia 2001 roku o odpadach (Dz.U. z 2007 r., nr 39, poz. 251 tekst jednolity) odpady oznaczają każdą substancję lub przedmiot należący do jednej z kategorii, określonych w załączniku nr 1 do ustawy, których posiadacz pozbywa się (lub do ich pozbycia jest zobowiązany) [1]. 
furnace slag are classified as ecologically safe green wastes, according to Waste Shipment Regulation No $1013 / 2006$ [2].

The use of green listed wastes in contemporary production technologies is part of the sustainable development strategy, in which environmental protection is one of the assumptions. Definition of sustainable development, which was approved in Rio de Janeiro in 1992 on Earth Summit, is as follows: „Development that meets the needs of the present without compromising the ability of future generations to meet their own needs". Currently, it is expected that manufacturing industry does not emit harmful substances to the environment, and obtained products are friendly and suitable for recycling. Glass is both human and environmental friendly, but it is material with some defects. The main problem is glass fragility, which is the reason of striving for the improvement of mechanical properties by controlled crystallization. Additionally, secondary raw materials are increasingly used due to environmental protection and obtaining better mechanical properties of glassceramics [3-5].

Fly ash is one of the by-products of energy industry, which can be used in glass-ceramics production. The production of electricity in Poland is mainly based on coal $(96 \%)$, and the side effect is huge amount of furnace wastes. From this reason, the main aim and the priority of environmental policy of the state is protection of natural environment by searching for new ways of waste management. Various types of coal and varieties of power boilers cause that fly ash has variable properties, which is very important in their re-use in industry. Currently, fly ash is used on a large scale in cement industry, road construction, ceramics, agriculture or plastics and paint industries [6-8].

The most common and the most important hydraulic additive used in cement production is granulated blast-furnace slag. Despite the fact that it is a waste, it is also used in the production of masonry mortars, slag bricks and as a material for the construction of roads and highways. Granulated blast-furnace slag was one of the first secondary raw materials used in glass-ceramics production [9].

Glass strengthening by controlled crystallization is not used on large scale in Poland, and therefore this paper focuses on the possibility of using the aforementioned secondary raw materials in glassceramics production.
Popiół lotny krzemionkowy oraz granulowany żużel wielkopiecowy klasyfikowany jest według Dyrektywy $\mathrm{Nr}$ 1013/2006 „Waste Shipment Regulation” jako ekologicznie bezpieczne odpady zielone [2].

Zastosowanie zielonych surowców odpadowych we współczesnych technologiach produkcji wpisuje się w strategię zrównoważonego rozwoju, w której jednym z założeń jest ochrona środowiska naturalnego. Definicja zrównoważonego rozwoju, którą przyjęto w Rio de Janeiro w 1992 r. na „Szczycie Ziemi”, jest następująca: „Rozwój zaspokajający potrzeby dzisiejszej generacji bez konieczności ograniczania możliwości zaspokajania potrzeb przyszłych pokoleń”. Obecnie dąży się do tego, aby przemysł produkcyjny nie emitował substancji szkodliwych dla środowiska, a otrzymany wyrób był przyjazny i nadawał się do recyklingu. Szkło jest materiałem przyjaznym zarówno dla człowieka, jak i środowiska naturalnego, jednak nie jest materiałem pozbawionym wad. Głównym problemem jest jego kruchość, w związku z tym w technologii materiałowej dąży się do poprawy właściwości mechanicznych tego materiału przez kierowaną krystalizację. Dodatkowo, ze względu na ochronę środowiska oraz uzyskanie lepszych właściwości mechanicznych szkła-ceramiki, coraz częściej stosowane są surowce wtórne [3-5].

Jednym z ubocznych produktów przemysłu energetycznego, które mogą być stosowane $\mathrm{w}$ produkcji szkło-ceramika, są popioły lotne. Produkcja energii elektrycznej w Polsce bazuje głównie na węglu (96\%), a efektem ubocznym jest ogromna ilość odpadów paleniskowych. Dlatego też głównym celem oraz priorytetem polityki ekologicznej państwa jest ochrona środowiska naturalnego przez poszukiwanie nowych sposobów zagospodarowania odpadów. Różne gatunki węgla oraz odmiany kotłów energetycznych przyczyniają się do tego, że popioły lotne mają różnorakie właściwości, co ma istotne znaczenie do ich ponownego wykorzystania w przemyśle. Obecnie popioły są wykorzystywane na szeroką skalę w przemyśle cementowym, drogownictwie, ceramice, rolnictwie czy też w przemyśle tworzyw i farb [6-8].

Najpowszechniejszym i najważniejszym dodatkiem hydraulicznym stosowanym $\mathrm{w}$ produkcji cementu jest granulowany żużel wielkopiecowy. Mimo tego że jest to odpad, znajduje on zastosowanie również w produkcji zapraw murarskich, cegieł żużlowych, jak również jako materiał do budowy dróg i autostrad. Granulowany żużel wielkopiecowy był jednym z pierwszych surowców wtórnych stosowanych podczas produkcji szkło-ceramika [9]. 


\section{PRODUCTION OF GLASS-CERAMICS MATERIAL}

Glass-ceramics material was discovered in 1953. It is polycrystalline material obtained by controlled crystallization, which results in formation of a material with very favourable mechanical, chemical and thermal properties [3].

Glass devitrification is heterogeneous transformation, which consists of two stages: nucleation stage and crystallization stage (Fig. 1). Nucleation stage involves material heating to the maximum nucleation temperature, and then its holding in furnace by specified time. During nucleation stage, small, stable crystalline products are formed in positions previously occupied by parent glass or free spaces. The latter are usually undesirable, because large oriented crystals, which are formed, are detrimental to mechanical properties of glass-ceramics material. Nucleation stage ends when stable nucleus has been formed and the crystals growth has been occured, thus the movement of atoms/ molecules from the glass, across the glass-crystal interface, and into the crystal. Then, temperature increases to $T_{G}$. Nucleation $\left(T_{N}\right)$ and crystallization temperatures $\left(\mathrm{T}_{\mathrm{G}}\right)$ are determined on the basis of differential thermal analysis - DTA [3].

Glass-ceramics material is not fully crystalline typical microstructure of glass-ceramics consists of crystalline products from $55 \%$ to $95 \%$, while the rest is residual glass. One or more phases are formed during controlled crystallization. The quantity and also the type of formed phases mainly depend on composition of parent glass and used reaction accelerators [3].
W Polsce wzmocnienie szkła przez kierowaną krystalizację nie jest wykorzystywane na szeroką skalę, dlatego w artykule skupiono się nad możliwością wykorzystania wyżej wymienionych surowców wtórnych w produkcji szkło-ceramika.

\section{OTRZYMYWANIE MATERIAŁU SZKŁO-CERAMIKA}

Tworzywo szkło-ceramika zostało odkryte w 1953 roku. Jest to materiał polikrystaliczny, otrzymywany przez kierowaną krystalizację, która prowadzi do otrzymania tworzywa o bardzo dobrych właściwościach mechanicznych, chemicznych i termicznych [3].

Dewitryfikacja szkła jest reakcją heterogeniczną, która przebiega $\mathrm{w}$ dwóch etapach: zarodkowanie (nukleacja) oraz krystalizacja (rys. 1). Etap nukleacji polega na wygrzewaniu materiału do maksymalnej temperatury zarodkowania, a następnie przebywaniu materiału przez określony czas w piecu. Podczas zarodkowania powstają niewielkie, stabilne produkty krystaliczne w miejscach szkła macierzystego lub w wolnych przestrzeniach. Te ostatnie są zwykle niepożądane, ponieważ powstające duże zorientowane kryształy wpływają na pogorszenie właściwości mechanicznych tworzywa szkło-ceramika. Etap zarodkowania kończy się, gdy powstanie stabilne jądro oraz dojdzie do wzrostu kryształów, czyli ruchu atomów/molekuł ze szkła przez powierzchnię międzyfazową do kryształu. Następnie ma miejsce wzrost temperatury do $T_{G}$. Temperaturę zarodkowania $\left(\mathrm{T}_{\mathrm{N}}\right)$ oraz krystalizacji $\left(\mathrm{T}_{\mathrm{G}}\right)$ wyznacza się na podstawie analizy termicznej DTA [3].

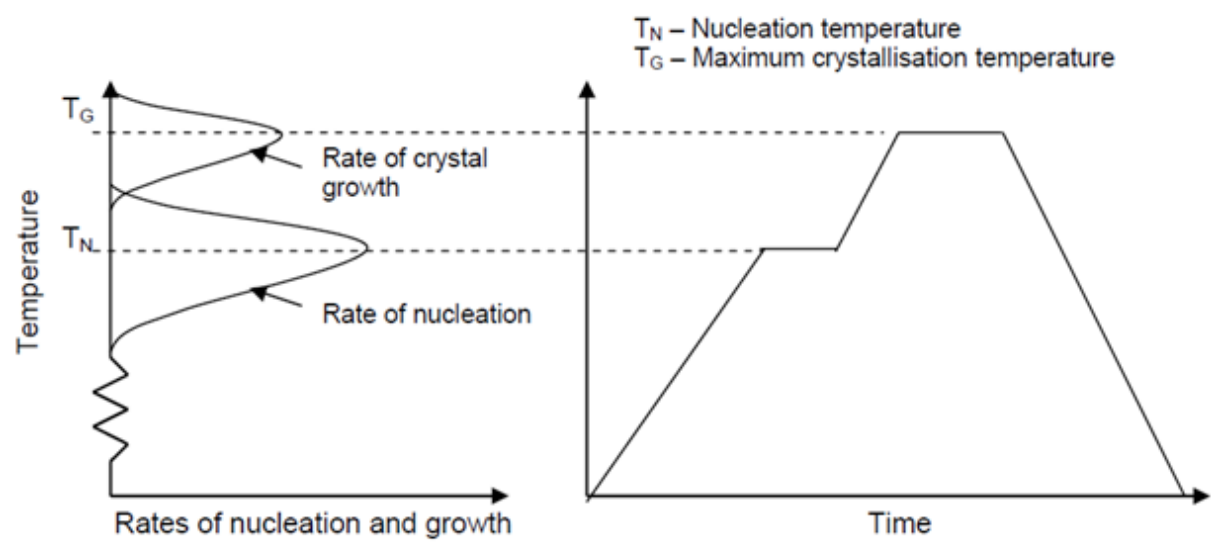

(a) (b)

Fig. 1. Glass crystallization results in glass-ceramics formation [3]

Rys. 1. Krystalizacja szkła prowadzaca do otrzymania szkła-ceramiki [3] 


\section{WASTE MATERIALS USED DURING GLASS-CERAMICS PRODUCTION}

Many papers presenting various examples of the use of secondary raw materials for glass-ceramics production are available. It is important that such secondary raw materials contain alkali oxides $\left(\mathrm{Na}_{2} \mathrm{O}\right.$, $\mathrm{K}_{2} \mathrm{O}$ ) and minor oxides (e.g. $\mathrm{TiO}_{2}$ ). The occurrence of these oxides affects, for example, the reduction of temperature of glass formation. It should be underlined that properties of glass-ceramics material depend on recrystallization degree, microstructure and properties of glassy phase remaining in the material.

There are several basic reasons for the utilization and re-use of secondary raw materials in the production of glass-ceramic material. One of them concerns the reduction of costs of secondary raw materials removal, the second is associated with minimizing of the use of natural resources, and the other one concerns the possibility of obtaining the material with better physical or mechanical properties compared to the material without waste materials [3-10].

The use of granulated blast-furnace slag and siliceous fly ash for glass-ceramics production is described in this paper.

\subsection{Granulated blast-furnace slag}

Metallurgical slag is one of the most differential secondary raw materials. Chemical composition of granulated blast-furnace slag is changeable and depends on the type of raw material used in a given metallurgical process. Complex nature of raw material depends on chemical composition of final product and waste material formed at the same time. Exemplary chemical composition and microstructure of blast-furnace slag are presented in Table 1 and Figure 2.

\begin{tabular}{|c|c|}
\hline Chemical composition & {$[\%]$} \\
\hline $\mathrm{L} .0 . \mathrm{I}$. & 0.02 \\
\hline $\mathrm{SiO}_{2}$ & 40.39 \\
\hline $\mathrm{Al}_{2} \mathrm{O}_{3}$ & 7.77 \\
\hline $\mathrm{Fe}_{2} \mathrm{O}_{3}$ & 0.99 \\
\hline $\mathrm{CaO} 0$ & 43.69 \\
\hline $\mathrm{MgO}$ & 3.77 \\
\hline $\mathrm{Na}_{2} 0$ & 0.53 \\
\hline $\mathrm{K}_{2} \mathrm{O}$ & 0.54 \\
\hline $\mathrm{TiO}_{2}$ & 0.33 \\
\hline $\mathrm{P}_{2} \mathrm{O}_{5}$ & 0.02 \\
\hline $\mathrm{SO}_{3}$ & 1.62 \\
\hline $\mathrm{Mn}_{2} O_{3}$ & 0.29 \\
\hline $\mathrm{SrO}$ & 0.04 \\
\hline
\end{tabular}

Tworzywo szkło-ceramika nie jest w pełni materiałem krystalicznym - typowa mikrostruktura szkło-ceramika to od $55 \%$ do $95 \%$ produkty krystaliczne, zaś resztę stanowi szkło szczątkowe. Podczas kontrolowanej krystalizacji powstaje jedna bądź więcej faz. Ilość, jak również rodzaj powstających faz zależy głównie od składu szkła wyjściowego oraz użytych katalizatorów reakcji [3].

\section{MATERIALY ODPADOWE STOSOWANE PODCZAS PRODUKCJI SZKKO-CERAMIKA}

W literaturze można znaleźć wiele przykładów wykorzystania surowców wtórnych przy produkcji szkła-ceramiki. Ważne jest to, aby takie surowce zawierały tlenki alkaliów $\left(\mathrm{Na}_{2} \mathrm{O}, \mathrm{K}_{2} \mathrm{O}\right)$ oraz tlenki akcesoryczne (np. $\mathrm{TiO}_{2}$ ). Obecność tych tlenków wpływa między innymi na obniżenie temperatury powstawania szkła. Należy w tym miejscu zaznaczyć, że na właściwości tworzywa szkło-ceramicznego wpływać będzie stopień przekrystalizowania, mikrostruktura oraz właściwości pozostałej w materiale fazy szklistej.

Istnieje kilka zasadniczych przesłanek za utylizacją i ponownym wykorzystaniem surowców wtórnych $\mathrm{w}$ produkcji tworzywa szkło-ceramicznego. Jeden z nich dotyczy zmniejszenia kosztów usuwania surowców wtórnych, drugi odnosi się do zminimalizowania wykorzystania surowców naturalnych, zaś kolejny do możliwości uzyskania materiału o lepszych właściwościach fizycznych bądź mechanicznych, w porównaniu do tworzywa bez dodatku surowców odpadowych [3-10].

W niniejszym artykule zostanie omówione wykorzystanie granulowanego żużla wielkopiecowego oraz popiołów lotnych krzemionkowych do produkcji szkło-ceramika.

\subsection{Granulowany żużel wielkopiecowy}

Żużle hutnicze stanowią jeden z najbardziej zróżnicowanych surowców wtórnych. Skład chemiczny granulowanego żużla wielkopiecowego jest zmienny i zależy od rodzaju materiału wsadowego stosowanego w danym procesie hutniczym. Złożony charakter materiału wsadowego wpływa na skład chemiczny produktu końcowego oraz powstającego równolegle

Table 1. Chemical composition of granulated blast-furnace slag. Source: own elaboration

Tabela 1. Skład chemiczny granulowanego żużla wielkopiecowego. Źródto: opracowanie własne 
Granulated blast-furnace slag was the first waste material used in glass-ceramics production in 1960, known as „Slagceram”. Slag mainly consists of such oxides as $\mathrm{CaO}, \mathrm{SiO}_{2}, \mathrm{Al}_{2} \mathrm{O}_{3}$ and $\mathrm{MgO}$, the rest are oxides occuring in small amounts. Small content of titanium oxide has a beneficial effect of the first stage of controlled crystallization, thus nucleation, which includes the entire volume. In the case of absence of $\mathrm{TiO}_{2}$ the crystallization proceeds only on the surface. Nucleation temperature of slag is about $725^{\circ} \mathrm{C}$, and crystallization temperature is $950-1100^{\circ} \mathrm{C}$. The crystallization is not completed below $950^{\circ} \mathrm{C}$. Small amounts of gehlenite $\left(\mathrm{Ca}_{2} \mathrm{Al}_{2} \mathrm{SiO}_{7}\right)$ and merwinite $\left[\mathrm{Ca}_{3} \mathrm{Mg}\left(\mathrm{SiO}_{4}\right)_{2}\right]$ are observed as final product. In the case of titanium oxide addition from $2 \%$ to $5 \%$, melilites containing gehlenite and akermanite $\left(\mathrm{Ca}_{2} \mathrm{MgSi}_{2} \mathrm{O}_{7}\right)$ are observed $[3,9,11]$.

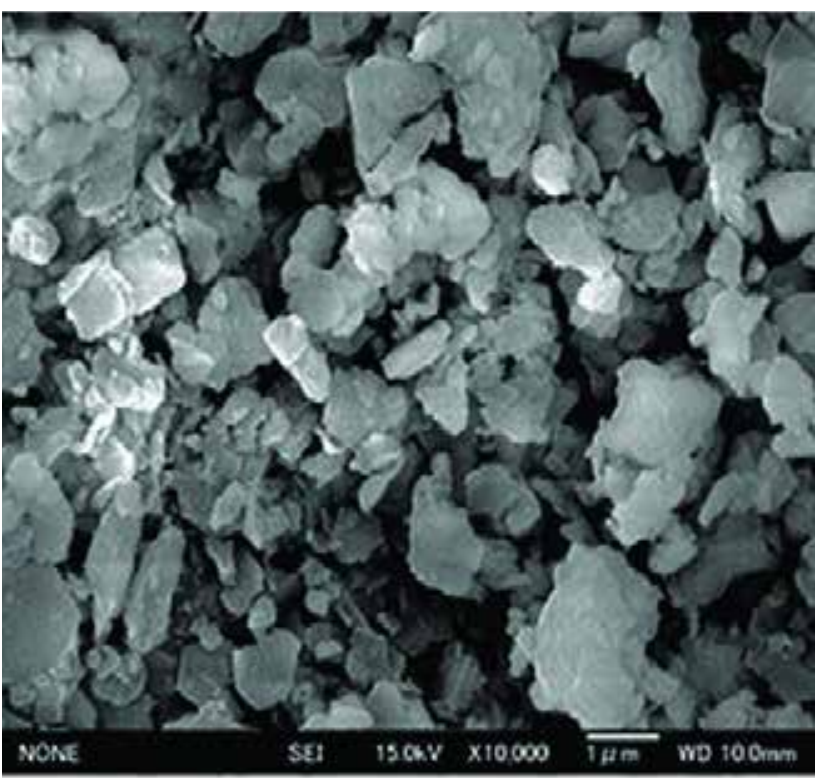

\subsection{Fly ash}

Siliceous fly ash is the most widely used material in technology of cement and concrete. In Poland, it is primarily obtained from black coal. Main components of fly ash given as oxides are $\mathrm{SiO}_{2}, \mathrm{Al}_{2} \mathrm{O}_{3}, \mathrm{Fe}_{2} \mathrm{O}_{3}, \mathrm{CaO}$, $\mathrm{SO}_{3}, \mathrm{MgO}, \mathrm{K}_{2} \mathrm{O}$ and $\mathrm{Na}_{2} \mathrm{O}$. Chemical composition of siliceous fly ash is presented in Table 2 .

Well visible spherical various sizes particles of fly ash are observed on micrograph taken from the scanning electron microscope (Fig. 3). materiału odpadowego. Przykładowy skład oraz mikrostrukturę żużla wielkopiecowego zestawiono odpowiednio w tabeli 1 oraz na rysunku 2 .

Granulowany żużel wielkopiecowy był pierwszym materiałem odpadowym stosowanym $\mathrm{w}$ produkcji szkło-ceramika w roku 1960, znanym pod nazwą Slagceram. Żużel składa się głównie z takich tlenków jak $\mathrm{CaO}, \mathrm{SiO}_{2}, \mathrm{Al}_{2} \mathrm{O}_{3}$ oraz $\mathrm{MgO}$, resztę stanowią tlenki występujące w małych ilościach. Niewielka zawartość tlenku tytanu wpływa korzystnie na pierwszy etap kontrolowanej krystalizacji, czyli zarodkowanie, który przebiega w całej objętości. W przypadku braku $\mathrm{TiO}_{2}$ krystalizacja przebiega wyłącznie na powierzchni. Temperatura nukleacji żużli wynosi około $725^{\circ} \mathrm{C}$, zaś krystalizacji $950-1100^{\circ} \mathrm{C}$. Poniżej temperatury $950^{\circ} \mathrm{C}$ krystalizacja nie przebiega do końca. Jako produkt końcowy obserwuje się niewielkie ilości gehlenitu $\left(\mathrm{Ca}_{2} \mathrm{Al}_{2} \mathrm{SiO}_{7}\right)$ i merwinitu $\left(\mathrm{Ca}_{3} \mathrm{Mg}\left(\mathrm{SiO}_{4}\right)_{2}\right)$. Przy dodatku od $2 \%$ do $5 \%$ tlenku tytanu obserwuje się w układzie melility zawierające gehlenit oraz akermanit $\left(\mathrm{Ca}_{2} \mathrm{MgSi}_{2} \mathrm{O}_{7}\right)[3,9,11]$.

Fig. 2. Microstructure of granulated blast-furnace slag [11] Rys. 2. Mikrostruktura granulowanego żużla wielkopiecowego [11]

\subsection{Popioły lotne}

Najszersze zastosowanie $\mathrm{w}$ technologii cementu oraz betonu mają popioły lotne krzemionkowe. W warunkach krajowych otrzymuje się je przede wszystkim $\mathrm{z}$ węgli kamiennych. Głównym składnikiem popiołów w przeliczeniu na tlenki $\mathrm{są}_{\mathrm{SiO}_{2}}, \mathrm{Al}_{2} \mathrm{O}_{3}, \mathrm{Fe}_{2} \mathrm{O}_{3}, \mathrm{CaO}$, $\mathrm{SO}_{3}, \mathrm{MgO}, \mathrm{K}_{2} \mathrm{O}$ i $\mathrm{Na}_{2} \mathrm{O}$. Skład chemiczny popiołu lotnego krzemionkowego zamieszczono w tabeli 2.

$\mathrm{Na}$ obrazie $\mathrm{z}$ elektronowego mikroskopu skaningowego zaobserwowano dobrze widoczne kuliste ziarna popiołu lotnego o różnej wielkości (rys. 3). 


\begin{tabular}{|c|c|}
\hline Chemical composition & {$[\%]$} \\
\hline $\mathrm{L} .0 .1$. & 2.44 \\
\hline $\mathrm{SiO}_{2}$ & 49.57 \\
\hline $\mathrm{Al}_{2} \mathrm{O}_{3}$ & 27.96 \\
\hline $\mathrm{Fe}_{2} \mathrm{O}_{3}$ & 9.03 \\
\hline $\mathrm{CaO}$ & 3.21 \\
\hline $\mathrm{MgO} 0$ & 2.09 \\
\hline $\mathrm{Na}_{2} 0$ & 1.42 \\
\hline $\mathrm{K}_{2} \mathrm{O}$ & 2.59 \\
\hline $\mathrm{TiO}_{2}$ & 1.19 \\
\hline $\mathrm{ZnO} \mathrm{SO}_{3}$ & 0.05 \\
\hline $\mathrm{P}_{2} \mathrm{O}_{5}$ & 0.03 \\
\hline $\mathrm{Mn}_{2} \mathrm{O}_{3}$ & 0.31 \\
\hline $\mathrm{SrO}$ & 0.06 \\
\hline
\end{tabular}

Table 2. Chemical composition of siliceous fy ash. Source: own elaboration

Tabela 2. Skład chemicznypopiolulotnegokrzemionkowego. Źródto: opracowanie własne

Fig. 3. Microstructure of siliceous fly ash [12] Rys. 3. Mikrostruktura popiołu lotnego krzemionkowego [12]

The first attempts to produce glass-ceramics from fly ash were taken in the 1980 s by DeGuire and Risbud. Siliceous fly ash was melted at temperature of $1500^{\circ} \mathrm{C}$, and then controlled crystallization was conducted at temperature of $650-700^{\circ} \mathrm{C}$ and $1000^{\circ} \mathrm{C}$, respectively for 2 and 5 hours. As the authors have observed, content of crystalline products was low (about 25\%), which they attributed to the limited amount of $\mathrm{TiO}_{2}$ as a factor facilitating nucleation (heterogeneous nucleation). Cumposton et al., by using $20 \%$ of $\mathrm{CaCO}_{3}$ and $\mathrm{TiO}_{2}$ as nucleators, have obtained material with content of crystalline products over $40 \%$, in which anorthite $\mathrm{Ca}\left[\mathrm{Al}_{2} \mathrm{Si}_{2} \mathrm{O}_{8}\right]$ was the main phase. Additionally, the occurrence of calcium carbonate influenced the decrease of viscosity and glass melting temperature by $100^{\circ} \mathrm{C}\left(1400^{\circ} \mathrm{C}\right)$. Small $\mathrm{TiO}_{2}$ addition influences the microstructure change, as well as the reduction of temperature of glass devitrification (Fig. 4) [3, 4, 6-8, 10].

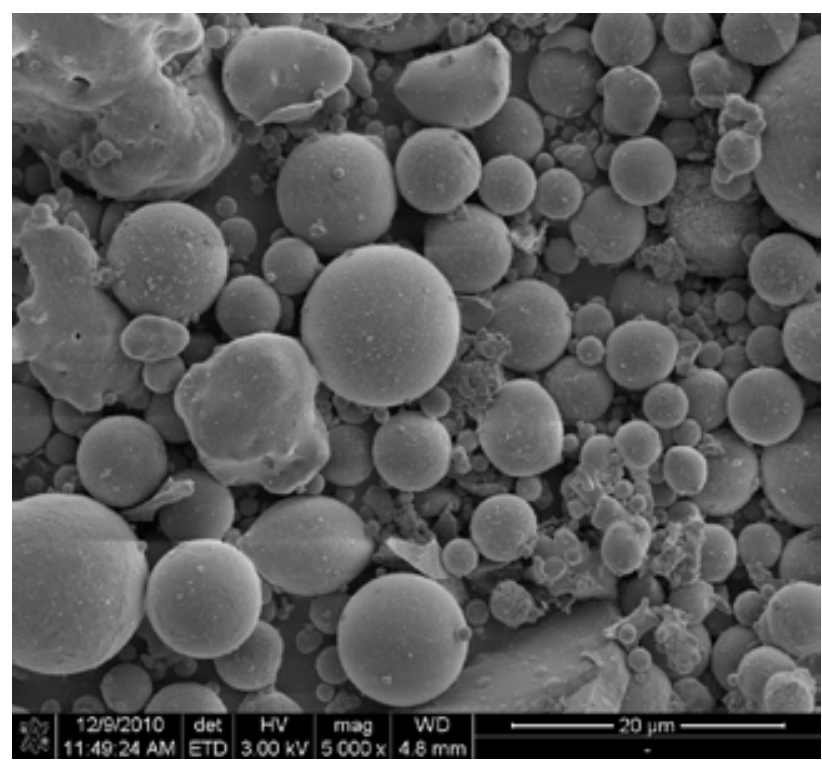

Pierwsze próby otrzymania szkła-ceramiki z popiołów zostały podjęte w latach 80. przez DeGuire i Risbuda. Popioły lotne krzemionkowe zostały stopione $\mathrm{w}$ temperaturze $1500^{\circ} \mathrm{C}$, a następnie poddane kontrolowanej krystalizacji w temperaturze 650$700^{\circ} \mathrm{C}$ oraz $1000^{\circ} \mathrm{C}$, odpowiednio przez 2 i 5 godzin. Jak zauważyli autorzy, zawartość produktów krystalicznych była mała (około $25 \%$ ), co przypisywali ograniczonej ilości $\mathrm{TiO}_{2}$ jako czynnika ułatwiającego zarodkowanie (nukleacja heterogeniczna). Cumposton i inni, przy użyciu $20 \% \mathrm{CaCO}_{3}$ oraz $\mathrm{TiO}_{2}$ jako nukleatorów, otrzymali ponad $40 \%$ zawartość produktów krystalicznych, w której główną fazą był anortyt $\mathrm{Ca}\left[\mathrm{Al}_{2} \mathrm{Si}_{2} \mathrm{O}_{8}\right]$. Dodatkowo obecność węglanu wapnia wpłynęła na obniżenie lepkości oraz temperatury topnienia szkła o $100^{\circ} \mathrm{C}\left(1400^{\circ} \mathrm{C}\right)$. Niewielki dodatek $\mathrm{TiO}_{2}$ wpływa na zmianę mikrostruktury, jak również na obniżenie temperatury dewitryfikacji szkła (rys. 4) [3, 4, 6-8, 10]. 

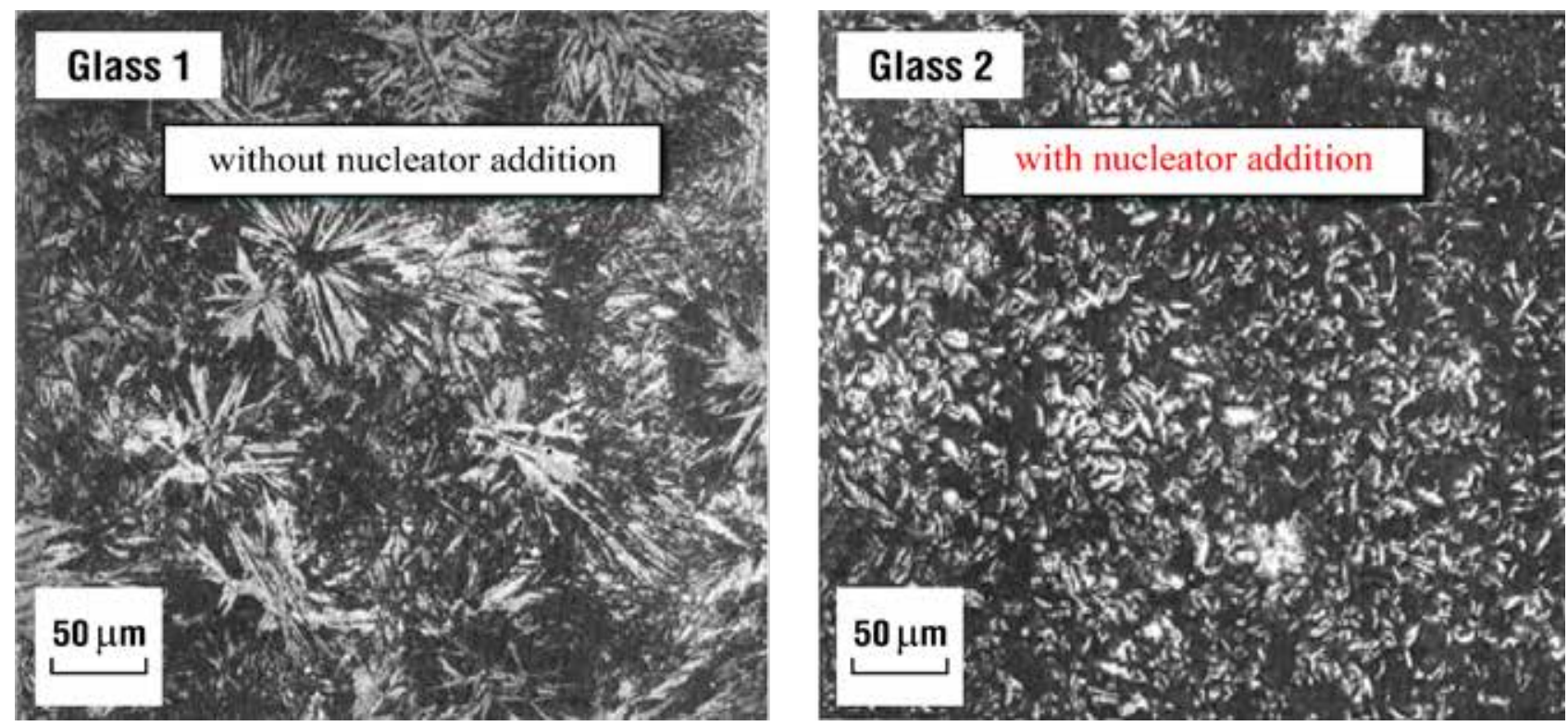

Fig. 4. Comparison of glass with nucleator (right) and without nucleator addition (left) [8]

Rys. 4. Porównanie szkta bez i z dodatkiem nukleatora [8]

\section{APPLICATION}

Glass-ceramics material has high mechanical strength, good resistance to temperature changes at values of $800-1000^{\circ} \mathrm{C}$. This material has practically no thermal expansion coefficient. It transmits visible and infrared radiation easily.

Due to its favourable properties, glass-ceramics material is used as heating plates, fireplace glass and radiator covers.

\section{SUMMARY}

Granulated blast-furnace slag and siliceous fly ash have been used in glass-ceramics production from many years. However, due to difficulties in obtaining adequate quantities of high-quality siliceous fly ash and granulated blast-furnace slag during periods of the highest cement demand in Poland, interest in other green recyclables increased - for example calcareous fly ash. Extremely important is further development of glass-ceramics material in view of its unquestionable technical advantages. Research works concerning the use of green secondary raw materials are aimed at improving certain properties or obtaining special properties of this material.

\section{ZASTOSOWANIE}

Materiał szklano-ceramiczny charakteryzuje się dużą wytrzymałością mechaniczną, odpornością na zmiany temperatury rzędu $800-1000^{\circ} \mathrm{C}$. Materiał ten ma praktycznie zerowy współczynnik rozszerzalności cieplnej. Dobrze przepuszcza promieniowanie widzialne i podczerwone.

Dzięki swoim szerokim właściwościom tworzywo szklano-ceramiczne znajduje zastosowanie jako płyty grzejne, szyby kominkowe oraz osłony grzejników.

\section{PODSUMOWANIE}

Granulowany żużel wielkopiecowy oraz popioły lotne krzemionkowe stosowane są $\mathrm{w}$ produkcji szkła-ceramiki od lat. Jednak trudności w pozyskaniu w Polsce odpowiednich ilości wysokiej jakości popiołów lotnych krzemionkowych oraz granulowanego żużla wielkopiecowego w okresach największego zapotrzebowania na cement spowodowały wzrost zainteresowania innymi zielonymi surowcami wtórnymimiędzy innymi popiołami lotnymi wapiennymi. Niezwykle ważny jest dalszy rozwój tworzywa szklano-ceramicznego, ze względu na jego niekwestionowane zalety techniczne. Prowadzenie prac badawczych nad zastosowaniem zielonych surowców wtórnych ma na celu poprawę pewnych właściwości lub uzyskanie specjalnych właściwości tego materiału. 


\section{References}

[1] Dziennik Ustaw z 2007, nr 39, poz. 251.

[2] Rozporządzenie (WE) Nr 1013/2006 Parlamentu Europejskiego i Rady z dnia 14 czerwca 2006. www.eurlex.europa. eu w sprawie przemieszczania odpadów, odwiedzono 25.10.2017 $\mathrm{r}$.

[3] Rawlings R.D., Wu J.P., Boccaccini A.R., Glass-ceramics: Their production from wastes- A Review, Journal of Materials Science, vol. 41, Issue 3, 2006, 733-761.

[4] Erol M., Küçükbayrak, Ersoy-Meriçboyu A., Production of glass-ceramics obtained from industrial wastes by means of controlled nucleation and crystallization, Chemical Engineering Journal 132, 2007, 335-343.

[5] Zanotto E.D., A bright future for glass-ceramics, The American Ceramic Society Bulletin 89, 8, 2010, 19-27.

[6] Erol M., Genç A., Öveçoĝlu M.L., Yücelen E., Küçükbayrak, Taptık Y., Characterization of a glass-ceramic produced from thermal power plant fly ashes, Journal of European Ceramic Society 20, 2000, 2209-2214.

[7] Leroy C., Ferro M.C., Monteiro R.C.C, Fernandes M.H.V., Production of glass-ceramics from coal ashes, Journal of European Ceramic Society 21, 2001, 195-202.

[8] Bernardo E., Castellan R., Hreglich S., Sintered glass-ceramics from mixtures of wastes, Ceramics International 33, 2007, 27-33.

[9] Liu H., Lu H., Chen D., Wang H., Xu H., Zhang R., Preparation and properties of glass-ceramics derived from blastfurnace slag by a ceramic-sintering process, Ceramics International 35, 2009, 3181-3184.

[10] Peng F., Liang K., Hu A., Nano-crystal glass-ceramics obtained from high alumina coal fly ash, Fuel 84, 2005, 341-346.

[11] Khan S.U., Nuruddin M.F., Ayub T., Shafiq N., Effects of Different Mineral Admixtures on the Properties of Fresh Concrete, The Scientific World Journal, 2014, 1-11.

[12] Chaipanich A., Nochaiya T., Wongkeo W., Torkittikul P., Compressive strength and microstructure of carbon nanotubes-fly ash cement composites, Materials Science and Engineering A 527, 2010, 1063-1067.

\section{Acknowledgments:}

This work was supported by Ministry of Science and Higher Education, Grant No. 3NS11K17 - Institute of Ceramics and Building Materials, Glass and Building Materials Division in Cracow

\section{Podziękowania:}

Praca finansowana przez Ministerstwo Nauki i Szkolnictwa Wyższego, praca statutowa nr 3NS11K17-Instytut Ceramiki i Materiatów Budowlanych Oddziat Szkła i Materiatów Budowlanych w Krakowie 